\title{
Origin and Development of Commercial and Islamic Banking Operations
}

\author{
Abdelkader Chachi \\ Islamic Economics Research Centre \\ King Abdul Aziz University, Jeddah, Saudi Arabia
}

\begin{abstract}
Banking is often considered by most economists as a modern device of recent origin $\left(12^{\text {th }}\right.$ Century $\mathrm{AD}$ Italy), but a glance, at the origin and development of financial operations throughout history, will dispel the notion of novelty as we can see from this paper.

The purpose of this paper is:

- Firstly, to show that banking operations were practised by almost all known early civilizations, long before $12^{\text {th }}$ Century AD Italy;

- Secondly, to prove that Islam not only allowed but encouraged such operations on a scale which surpassed anything known before;

- Thirdly, to show that the Italians bankers learnt these operations from the Muslim, Christian and Jewish traders of the Muslim world with whom they had long and strong commercial relationships between the $10^{\text {th }}$ and $12^{\text {th }}$ centuries AD; and

- Finally, to trace the origin and development of what is known nowadays as 'Islamic banking'.
\end{abstract}

\section{Introduction}

Jacob Burchard (cited by Lopez, 1979:1) said: "History is the one field of study that does not begin at the beginning". Banking, as one of the most specialised forms of commerce, appeared as did the latter in conjunction with the civilisations of the past and was nearly always at the basis of their prosperity, but as Orsingher (1967:1) put it: "It is impossible with the documents discovered so far, whatever their kind, to determine when banking operations first took place or to give a continuous uninterrupted account of their evolution". However, most economists maintain, as Bergier (1979:105) claims that: "Banking was Italian by birth". Firstly, because the technical word 'bank' is derived from the Italian word 'banco' which means a table or a bench on which Italian money-changers used to display their monies and records and conduct their transactions. Secondly, because they consider that the first banks, worthy of the name, were those established in Venice, Florence, Genoa and Lucca in Italy, during the $12^{\text {th }}$ century AD (see Usher, 1943 and De Roover, 1954). Thus, banking is often considered as a modern device of recent origin, but a glance through the pages of financial history will dispel the notion of novelty. 
In order to accomplish the purpose of this piece of research, the remaining of this paper is divided into the following sections:

- Section 2 traces the origin of banking operations in early civilizations.

- Section 3 shows how banking operations developed under the Muslim civilization up to the $12^{\text {th }}$ century AD.

- Section 4 shows how banking operations developed in Europe from the fall of the Roman civilization till the $12^{\text {th }}$ century Italy, mainly as a result of the close contact between South-Europe and the Muslim empire at the time.

- Section 5 focuses on the banking operations in the Muslim world from the fall of the Islamic empire to the emergence of what is now known as 'Islamic Banking' in the 1950s and 1960s.

- Section 6 presents the conclusion.

\section{Banking in Ancient Times}

\subsection{Banking in Prehistoric Times}

As Lopez (1979:1) put it: "Nobody knows when credit was first used as a lubricant of business and commerce, probably in prehistory, but banks of a sort existed in ancient Mesopotamia, Greece and Rome". According to Homer (1963:17) credit probably antedated industry, banking, coinage and even primitive forms of money. He contended: "When we consider credit in its broadest meaning, we can infer something of its earliest forms. Primitive credit need only have consisted of a loan of seed to a son or brother or neighbour until harvest time or a loan of an animal or of a tool or of a food. Such transfers are called gifts if no repayment is expected, loans if repayment is expected and loans at interest if the repayment of a certain amount, more than was loaned, is expected".

Before the days of the first recorded contracts and financial transactions, people used cattle, grain, silver or anything else they could agree on as currency to be used in a trade and credit (Davies, 2002:12). Unfortunately, there is no historical evidence available about these or other banking operations in prehistoric times.

\subsection{Banking in Mesopotamia}

Although it is impossible to establish when or where banking operations first started, it is clear, as Homoud (1985:17) argued that: "the need for it emerged and developed with the use of money as a means of exchange at the beginning of organised agriculture, industry and trade". The first civilisations, for which there is available historical evidence on banking operations, are the Sumerians and Babylonians, who lived about 34 centuries BC in Mesopotamia. Orsingher (1967:1) reported that: "Historical excavations have uncovered the temple of Uruk and Chaldea, a relic of the Babylonian empire, and have shown that the foundation of the -now known- oldest banking building in the world took place more than 3,300 years before our era". 
From the examination of the -up to now discovered- historical evidence in Mesopotamia, it would be inferred that in those days, banking was characterised by being related with sacred temples, which provided secure places for the safe-keeping of grain and other commodities. As Davies (2002:49) reported: "receipts came to be used for transfers not only to the original depositors but also to third parties. Eventually private houses in Mesopotamia also got involved in these banking operations".

The translation, of one of the scripts found in Mesopotamia, shows that a farmer had borrowed from the priestess of the temple a quantity of silver to finance his purchase of sesame. He undertook to pay for the equivalent of this silver in sesame at the price current at the harvest time to the holder of the credit document made payable to the bearer (Homoud, 1985:17-18). At least four observations can be made about this document:

- $\quad$ First, it shows that the temples used to act as, or play the role of banks, which may be explained by the fact that people used to have more confidence in their religious temples and priests than in others, because of the glory of sanctification of these temples and the belief that these would render accurate and complete account of deposit and that they were more secure than any other place since nobody would dare to steal from the sacred temples.

- Second, the customer is a producer, in other words the loan was for production purposes and not for consumption.

- Third, a credit document equivalent to a promissory note or a bill of exchange was given by the borrower as a credit evidence; not only that, but was made payable to the bearer which means that it was transferable.

- Fourth, there was no interest involved in the operation since the customer was required to pay only the equivalent of the silver he borrowed in sesame at the current price of the harvest time; which may be smaller, equal or greater than its price at the time of the borrowing. But even if it is greater, this would not be interest, since interest is the amount paid over and above the capital lent and from the same kind, such as silver on silver, or sesame on sesame, but not silver on sesame or sesame on silver.

Kings and private individuals were also among the large-scale capitalists bankers at that time. Investments took the form of loans of money or seed, the rate of interest was $20 \%$ for money and $33 \%$ for barley and the borrower as well as his family risked slavery for non payment of debt if he defaulted. The limited partnership Commenda which is very similar to Mudarabah was also a Babylonian invention. Bank operations by temples and great landowners had become so numerous and so important that the famous Babylonian King Hammurabi (1728-1686 BC) thought it was necessary to lay down standard rules of procedures, which could deal with nearly all cases arising from the terms of ownership of land, the employment of agricultural labour, civil obligations, loans, interest, pledges, guarantees, the presence or absence of evidence, natural accidents, loss, theft, etc., (Homer, 1963:26 and Orsingher, 1967:viii). However, after the Persian conquest around 539 BC, Mesopotamia lost her independence. Babylonia 
was no longer a great capital city; interest rate reached the level of $40 \%$ and became the common prevailing rate. Her old civilisation had all but vanished (Homer, 1963:31).

\subsection{Banking in India}

Historians believe that the most significant era in the history of early India is what is known as the 'Indus Valley Civilisation', also known as 'Harappan Civilization', in reference to its first excavated city of Harappa. It flourished between 3000 and 1800 $\mathrm{BC}$, comprising the whole of modern day Pakistan and parts of modern-day India and Afghanistan. This was among the world's earliest civilizations, contemporary to the great empires of Mesopotamia and Egypt. It reached its most prosperous phase in the $2600 \mathrm{BC}$ as an urban culture based on commerce and sustained by agricultural trade. Most likely, commercial dealings and banking operations such as lending and borrowing were abound, as in its neighbouring areas, like Mesopotamia, but little detail is known, as attempts made by historians in deciphering the Harappan scripts have been in vain until now. This civilisation declined between the $9^{\text {th }}$ and $17^{\text {th }}$ century BC, probably due to ecological changes or to the Aryan invasion, which appeared on the scene around this time (See Wikipedia website and Nationmaster website). However, in the period between $200 \mathrm{BC}$ and $200 \mathrm{AD}$, and according to Nigam (1971:305-306) trade, urban markets, fairs and exhibitions were organised on a systematic basis. The state was involved in constructing storehouses and in controlling the markets, thus preventing fraud, cheating hoarding, smuggling, etc..

Nigam (1971:307-311) mentions that different forms of business organisations were in vogue in ancient India (200 BC and 200 AD) especially partnerships and that credit was regarded as an important economic phenomenon. Wealthy persons and guilds were expected to conduct credit and banking operations.

Saletore (1975:35-101) tried to prove that there was an extensive international trade between India and the rest of the civilised world at the time, Babylon, Rome, Greece, Egypt, Persia and China prior to the $7^{\text {th }}$ century AD. He affirms that deposits, pledges, mortgages and endowments were made in various places by different persons from time to time and that in all these transactions, interest always played a prominent if not the most important role. He concludes by saying: "The levying and the recovery of interest have been two of the most vital functions of banking in India from very early ages" (Ibid.:668)

\subsection{Banking in Greece}

According to Orsingher (1967:3), the development of banking in early Greece was hampered by the level of local economic activity, the severity of local laws and the precarious state of trade and exchange until the invention of coin money. The question, which arises here is: who invented coin money? and when?. Orsingher (1967:viii) answered that: "Perhaps the Chinese, but no certainty exists on this point". King Croesus of Lydia (560-546 BC) is credited with providing the first ingots of pure gold when Lydia was then a leading producer of gold. However, the official coinage of money, as Einzig (1948:225); Homer (1963:33); Orsingher (1967:viii-ix) and Davies (2002:61-63) pointed out, is supposed to have originated in Lydia in the 7th Century BC. The first coins were attributed to King Cyges (687 BC) of Lydia. They were of 
electrum (a mixture of gold and silver). This must have encouraged the emergence and practice of banking operations in Greece because certain traders soon began to specialise in the evaluation and exchange of coins made from precious metals in various sizes and weights (Orsingher 1967:3).

The Greek bankers or trapezites, as they were also called -from the Greek word trapeza, meaning a table or a bench, on which they used to display moneys and conduct their transactions- changed money, received deposits, made loans to individuals and states, issued letters of credit, honoured promissory notes or cheques and kept complete books, so much so that, as Homer (1963:69) noticed: "in next to no time the commercial genius of the Greek rose to the point of speculation".

Perhaps under the influence of earlier civilisations, temples were also used as deposit takers and lenders in Greece. The Shrine of Delphi, is sometimes described as the great banker of the Greek world (Homer, 1963:38), but after the conquest of Alexandria (325 BC), and as Homer (1963:39) reported: "Athens was no longer in a position to dominate Mediterranean commerce. She had lost her empire... During the ensuing centuries, however, Rome, not Greece dominated the history of the Mediterranean world... Athens never regained her position as the great commercial and financial centre. As a consequence of Roman policy, trade shifted to Rhodes, Antioch, Selencia and especially to Alexandria".

\subsection{Banking in Rome}

The Romans, as described by Homer (1963:44), were a nation of farmers and soldiers. They left manufacture, commerce and banking mainly to foreigners. Most of the earliest bankers in Rome had Greek names and were called trapezites as well. Orsingher (1967:5-6) reported that: "There were no banking monopolies during the Roman period, and this liberty allowed banking operations to develop and flourish". By the first century BC, Rome was the banking centre of the Republic and of the Empire and probably of the world at the time. Bankers became so numerous that in addition to the name trapezites, they were later designated by names like: mensularii, argentarii, mummularii, etc. (Homer, 1963:47).

After 90 BC, banking operations experienced ups and downs depending on the political and military conditions of the Republic. In time of wars and disorder, inflation, financial stagnation and bankruptcy prevail and in times of peace and prosperity, financial stability is restored and banking operations and trade improved. In the third century $\mathrm{AD}$ monetary inflation on a grand scale accompanied a succession of revolutions and civil wars and the chaotic fifty years before Diocletian, 284-305 AD, were in the opinion of Frank (1933:300) "the period when Rome fell. There were anarchy and looting. Provincials lost faith in Rome. Industry and trade disintegrated and even the Latin speech decayed".

\subsection{Banking in Egypt}

According to Orsingher (1967:4): "Until the Alexandrian conquest, a primitive economic system persisted in Egypt, but the Ptolemites introduced coinage into Egypt and the same evolution which has been observed in Greece took place here also. Indeed, 
trapezites are to be found here as in Greece, but they are, in some sort, official agents; many of them have Greek names and the earliest of them came from Greece'. Even before the introduction of coinage in Egypt, banking operations started with harvests being stored in state warehouses (Netfundu, website). Davies (2002:51-54) reported that the centralization of harvests in state warehouses led to the development of a system of banking. Written orders for the withdrawal of separate lots of grain by owners whose crops had been deposited there for safety and convenience, or which had been compulsorily deposited to the credit of the king, soon became used as a more general method of payment of debts to other persons including tax gatherers, priests and traders. The numerous scattered government granaries were transformed into a network of grain banks with what amounted to a central bank in Alexandria where the main accounts from all the state granary banks were recorded. This banking network functioned as a giro system in which payments were effected by transfer from one account to another without money passing from one hand to another.

During the $1^{\text {st }}$ and $2^{\text {nd }}$ centuries $A D$, Egypt attained the highest stages of development in the art of banking and was rich and prosperous (Homoud, 1985:18). But in the $3^{\text {rd }}$ century $\mathrm{AD}$ the disorder of the Roman Empire broke through the barriers of Egypt's economic isolation, deliberately caused by a fiat currency that circulated for some time only in Egypt (Homer, 1963:51).

\subsection{Banking in Persia}

Persia is not one of the early cradles of civilization. It developed east of the Fertile Crescent on the Iranian plateau of central Asia, which was not settled until about 1500 BC by Aryan tribes, especially the Medes. The first great chief was Achaemenes who founded the Achaemenid dynasty about $700 \mathrm{BC}$. The Achaemenids built a great capital city at Persepolis. During this era, trade boomed and subsequently banking operations expanded especially after conquering Babylonia in 539 BC. Persian traders managed to learn the Babylonian banking methods. Merchants used both caravan and maritime routes to transport commodities between India and Persia. Following a boost in trade and use of bank notes and coins in trade during the Parthian and Sassanian eras, exchange of coins and hard currencies began in the country. Some people also managed to specialize in determining the purity of coins. Bank notes and gold coins were first used in the country following the conquest of Lidi by Achaemenid king Darius the Great in 516 BC (Tejarat, 1998, Scott, 2003, Herart, 1972).

According to Ghirshman et al. (1971:58-60) the Achaemenians introduced weights and measures and above all, coinage throughout the empire, which stimulated foreign commerce and facilitated banking activities. Private banks were established like the bank of the descendents of Igibi of Babylon, which was founded as early as the $7^{\text {th }}$ century BC and whose surviving records reveal that it carried on the operations of Pawn-broking, and floating loans among other things. Another bank that of Murashshu and sons at Nippur was founded later and held leases, dug canals and sold water to farmers.

\subsection{Banking in China}

Although, the first Chinese dynasty noted in Chinese records is the Xia dynasty, its existence has yet to be conclusively corroborated by archaeological evidence. It was not 
until the 1960s and 1970s that archaeologists have uncovered urban sites, bronze implements, and tombs in Henan Valley, the apparent cradle of Chinese civilization, which provide evidence about the Shang dynasty, which endured roughly from 15231027 BC. This was based on agriculture, augmented by hunting and animal husbandry (Findling and Thackeray, 2001:12-13). Cowries and metal models of valuable implements, such as spades, hoes and knives were accepted in commercial exchanges (Davies, 2002:55). Prior to this era, historians find it difficult to separate myth from reality. Two important events that mark this period, and that attest to a high level of civilization, were the development of a writing system, as revealed in archaic Chinese inscriptions found on tortoise shells and flat cattle bones and the use of bronze metallurgy (Columbia Encyclopaedia, 2004:10045).

Although the first recorded use of paper money was in the 7th century China, it did not become common until about 960 AD onwards. The Chinese Empire, short of copper for striking coins, issued the first generally circulating notes. The original notes were restricted in area and duration. A motive for one such early issue, in the reign of Emperor Hien Tsung 806-821 AD, was a shortage of copper for making coins. A drain of currency from China, partly to buy off potential invaders from the north, led to greater reliance on paper money with the result that by $1020 \mathrm{AD}$ the quantity issued was excessive, causing inflation. In subsequent centuries, there were several episodes of hyperinflation and after about $1455 \mathrm{AD}$, after nearly 500 years of using paper money, China abandoned it (Bamboo website, Wikipedia website).

\section{Banking in the Islamic Empire From the Rise of Islam till the $12^{\text {th }}$ Century}

According to Homoud (1985:19): "the period lasting from the fall of Rome until the dawn of Islam was the darkest, most corrupt and unsettled period in the known history of Man. Hence, the dawn of Islam removed darkness from the face of life and brought an environment of security and stability to the areas which came under the influence of Islam". The rise of Islam brought about a tremendous change in all economic, political, social and judicial spheres and brought about a new civilization that is based on the total and complete submission to Allah and his Shari'ah. Wilson (1950:40-53) describing the impact of Islam on world history, wrote: "The sudden eruption of the Arab (Muslim) people in the $7^{\text {th }}$ Century is something unique in history. In three generations a collection of scattered tribes, some settled, some nomadic, living by trade and subsistence farming, had transformed itself into a rich and powerful empire dominating the whole of southern Mediterranean and the Near-East from Afghanistan to Spain... They had succeeded in welding together peoples of diverse beliefs and languages into a unified society based on a common religion, a common language and common institutions". Lieber (1968:230) also contended that: "From the seventh century AD onwards, Muslims succeeded in developing long distance trade and international commerce on a scale which surpassed anything known before. This is, perhaps, because Islam is one great religion which affords the merchant a highly honoured place in society" and promises him an elevated position in paradise if he deals with honesty, justice and benevolence and perhaps, that is why many great Muslim scholars had, at some stage of their careers, earned their living as merchants (see Weit 1955). 
Lieber (1968:230) pointed out that: "Among Muslims, international trade was particularly stimulated by the pilgrimage to the holy places of Arabia, in which a great body of men converged each year from all over the world. Many of these pilgrims fulfilled their religious obligations and at the same time, marketed their local products along the route, returning home with foreign goods on which they hoped to make a handsome profit". With the development of trade, comes the development of banking operations, hence operations such as lending, borrowing, transferring, guaranteeing, safeguarding, etc., were all used extensively in Arabia.

Commenting on the statement of De Roover (1954:43) which says "There can be no banking where there are no banks", Udovitch (1979:255) argued: "This proposition may hold true for the development of banking in Medieval Europe but it certainly does not describe the Medieval Islamic world. In the sporadic information on this subject from Medieval literary or documentary sources, we encounter bankers and we encounter extensive and ramified banking activities but we do not encounter banks. That is, we cannot identify any autonomous or semi-autonomous institutions whose primary concern was dealing in money as specialised if not exclusive pursuit". However, the historical writings of al-Qalqashandi (1913), al-Djahshiyari (1938), Pellat and Schacht (1965), al-Kubaisi (1979), al-Ali (1953, 1981), al-Saadi (1985), al-Duri (1986, 1995), Fischel (1992), al-Hamdani (2000) and Chapra and Ahmed (2002) show that there were indeed bankers called sarraffeen or sayarifah or djahabidhah and banks called dawawin al-djahabidhah.

From the end of the 8th century, the term djahbadh (plural djahabidhah) was used in the sense of a financial clerk, expert in matters of coins, skilled money examiner, treasury receiver, government cashier, money changer or collector to designate the well known licensed merchant banker in the time of the Abbasid caliphs. In 913 AD, the state established what is called diwan al-djahabidhah (plural dawaween aldjahabidhah) with branches in the main trade cities conducting almost all modern banking functions albeit without recourse to interest. In the time of the caliph alMuqtadir (980-1032 AD) al-djahbadh assumed an ever increasing important role and emerged as a modern banker, who in addition to his functions as administrator of deposits and a remitter of funds from place to place via the medium of the sakk (cheque) and especially of the suftajah (bill of exchange), was called upon to grant huge loans to the caliphs, the viziers and other court officials (al-Qalqashandi 1913; al-djahshiyari, 1938, Pellat and Schacht 1965 and Metwalli and Shahata, 1983).

According to Metwalli and Shahata (1983:113-17), the chief djahbadh or governor of diwan al-djahabidhah was required by the state to prepare a monthly and a yearly accounting statement called al-khatmah (the final account or balance sheet) of all the items of income and expenditure. Historical sources, also, show that many of the djahabidhah were Christians or Jews despite their status as dhimmis (non Muslims living in Muslim society). Among the djahabidhah listed in the historical sources were: Ibrahim Bin Yuhanna, Zakariyah Ben Yuhanna, Sulayman Bin Wahb, Ibrahim Bin Ahmad, Israel Bin Salih and above all two Jewish merchants and bankers: Yusuf Bin Finkhas and Harun Bin Imran of Baghdad who were appointed to the office of djahbadh of the Persian province Ahwaz and later became djahabidhat al-hadrah (the Court 
bankers) of the caliph al-Muqtadir and his viziers (see Mez 1937; Goitein 1967, 1973; Udovitch 1970, 1979 and al-Sayed 1984).

As reported by Chapra and Khan (2000:1-3) and Chapra and Ahmed (2002:2-6) Muslims were, from the very early stage in Islamic history, able to establish a financial system without interest for mobilising resources to finance productive activities and consumer needs. The system was largely based on profit and loss sharing modes of mudarabah (passive partnership) and musharakah (active partnership). These bankers used to evaluate the authenticity and fineness of coins, which was very important function at that time when coins were made of precious metals. They used to put these coins in sealed bags of different sizes containing specified amounts of coins to relieve the people from the trouble of counting them every time they made or received a payment. They transferred funds from place to place without their physical transport and thereby ensured not only their safety but also the successful functioning of the payment system.

Al-djahabidhah used to advance loans to the state secured by the government tax revenues, which they used to collect. When they collect the tax revenues, they get their principal and an amount above it which some historians consider as interest (see Pellat and Schacht 1965:383). But if we take into consideration the efforts of collecting and administering the taxes, we can infer that the amount above the principal was not interest but a fee for the administration of the taxes, because on one hand, interest is forbidden and fees are allowed in Islam, and on the other hand, interest depend on the amount and period of loans, while fees or commissions are allowed to be paid for rendering services. Udovitch (1979:267) affirmed that: "whereas it was customary for merchants and others to keep at least a portion of their money on deposit with merchant bankers and whereas the merchant banks themselves kept deposits of various size with several other merchant banks, there is no evidence whatsoever that any interest or other type of premium was paid to depositors". This is so because Allah prohibits riba (interest) in many verses of the Holy Qur'an and provides several alternatives to riba such as musharakah (partnership), mudarabah (commenda), muzara'ah (sharecropping), etc., whereby the riba prohibition could be avoided.

In the early Middle-Ages, the Islamic empire played a great role in establishing the foundation of an economic golden age of which the players in the field of trade and banking were Arabs, Persians, Berbers, Jews, Christians and Armenians. Islamic trade reached from al-Andalus (Spain) to the sea of China. Pirenne (1937:49) contended: "In consequence of their worldwide trade relations, they (the Muslims) brought sugar cane from India, cotton to Sicily and Africa and rice to Sicily and Spain. They learned from the Chinese how to produce silk and paper and took this knowledge with them into all parts of their empire".

Lieber (1968:230) also observed that: "The merchants of Italy and other European countries obtained their first education in the use of sophisticated business methods from their counterparts on the opposite side of the Mediterranean, most of whom were Muslims, although a few were Jews or Christians. One obvious result is the large number of words of Eastern origin mainly Aramaic, Arabic or Persian, which were introduced into the commercial terminology of medieval Europe. Some examples of the 
terms (whose European usage was not necessarily identical with their original connotation) are: douane, arsenal, magazine, traffic, tariff, risk, fondaco, sensali, galeya, aval and maona".

To quote just a few more words, one might mention the English word cheque, which is originally from the Arabic word sakk; credit from qard, risk from rizq; the French words acheter from ishtara (to buy), le magasin from al-makhzen (warehouse), aval from hawala and the Spanish words almacen from al-makhzen, zoko from souq (market) and many others. (see Doi 1984:399; Vives 1969:119-20; Torrey 1892, Steigher 1963, Bantier, 1971). As Labib (1969:80) pointed out: "Everywhere that Islam entered, it activated business life, fostered an increasing exchange of goods and played an important part in the development of credit". Bantier (1971:72) also pointed out that: "Arab commerce extended over the whole of the then known world, and trade with China, Malaysia and India reached considerable proportions".

According to Udovitch (1979:263): "The suftaja (Bill of Exchange) always and the hawala (credit guarantee or credit transfer) usually occurred as a written obligation, and were thus the first and most important forms of commercial credit papers in the Medieval Near East". That is so, perhaps because of Allah's order to Muslims in the longest verse of the Holy Qur'an (2:282-3) to write down all future obligations.

After the 13th Century, the djahbadh lost his control significantly as a court banker, his function was reduced to that of a sarraf or sayrafi (money changer) as a result of the slow but prolonged decline of the Islamic Empire from about the 12th Century BC, due mainly to the following internal and external factors:

1. The gradual but continuous deviations from Islam and Islamic Shari'ah especially in the political sphere.

2. The extravagance and lavish expenditure of the courts.

3. The lack of organisation and the inflated bureaucracy.

4. The political breakdown, involving the loss of authority of the central government in the remote provinces and the emergence of petty dynasties and quasi-independent governors resulting in the degradation of the caliphs to the status of mere puppets of their ministers and military commanders.

5. The rise and development of different and antagonistic sects, all claiming to be the only real Muslims such as the Sufis, the Shi'ites, the Ismaelites, the Druzes, etc..

6. The prolonged warfare with the crusaders, Mongols and Tartars, which caused much destruction in Iraq and Syria.

7. The Turco-Persian wars, which dragged on for nearly three centuries and which impeded the economic recovery of Iraq.

Due to these and other historical circumstances, the Muslim world lost its technological and economic activity. Hence a number of the Islamic institutions, including the Islamic system of financial intermediation, became displaced by Western institutions (Issawi, 1966:4, Lewis, 1970:102 and Chapra, 2000:173-185, and Chapra and Khan, 2000:3). 


\section{Banking in Europe From the Fall of the Roman Empire till the $12^{\text {th }}$ Century AD}

From about $300 \mathrm{AD}$ time of the fall of the Roman Empire till about 1300 AD, Western Europe with the exception of Spain and Italy lived in dismal and bleak centuries called the 'Dark-Ages'. Spain, because it was part of the Islamic Empire under the name of al-Andalus, which was known by its great civilisation between the 8th and 15th Centuries AD and Italy because of its strategic commercial position in the Mediterranean and its regular contact with Muslim, Christian, and Jewish merchants of the Islamic Empire. In fact, Sicily and Venice were also part of the Islamic Empire for some time.

Following the fall of the Roman Empire, barbaric kingdoms prevailed throughout Western Europe. Commerce became profoundly depressed in Western Europe, which was, as Homer (1963:84) put it: "sinking back into a largely agricultural economy". This led the famous European historian Pirenne (1937:20) to say that in Western Europe: "La terre était tout et le commerce rien" (which means that the land (or agriculture) was everything and the commerce was nothing). This is not to suggest that there was no trade at all in Western Europe, but just to say that it was very limited as a consequence of political instability, uncertainty, high cost of transportation, heavy taxes and customs duties, piracy, bribery and illiteracy. Thus, if trade is limited, so must be the banking operations.

During these so called 'Dark Ages', and as reported by Homer (1963:84): "the Latin tongue was forgotten, culture vanished and superstition throve. However, money was used regularly throughout the darkest of the Dark-Ages but the lack of commerce reduced its circulation". Orsingher (1967:11) pointed out that: "during all the period which extends from the fall of the Roman Empire till the end of the 11th Century the banking industry in Western Europe was represented by the money changer. The age of the crusaders was the starting point for the development of monetary and credit operations during the $2^{\text {nd }}$ part of the Middle Ages". The $10^{\text {th }}$ Century was called the century of transition in which the crusaders managed, on one hand, to weaken the Islamic Empire -which had already shown weakness after the destructive raids of the Mongols and Tartars and after the rise of divergent petty dynasties within it- and on the other, to transfer the know-how from the Islamic civilisation to Western Europe, especially on how to promote irrigation, handicrafts, partnerships, trade and banking so that by the end of the 11th Century, political and economic revival in Western Europe generally and in Italy in particular became general. Thus, as Lopez (1952:273) described: "Italy at last began to exploit the advantage of her central position in regard to both continental Europe and the Mediterranean basin. A nation of moderately successful peasants and farmers who in Roman times were dependent upon Easterners for their trade and who did not produce enough food for their overgrown capital, now was on its way to becoming the first commercial and industrial nation in the world".

Venice, was perhaps the most prosperous town in Italy at that time where there was no serfdom and where the majority of its population was engaged in maritime trade, especially with the Muslim world, in spite of opposition from the Papacy. Coiners and money changers rose steadily in power and prestige; and commercial contracts, such as 
the commenda equivalent to the Islamic partnership contract of mudarabah which involved sleeping partnership, became a very popular device in Mediterranean commerce (see Homer, 1963:86-88 and Miskimin, 1969:118). This probably explains the observation of Lieber (1968:230) that: "The merchants of Italy obtained their first education in the use of sophisticated business methods from their counterparts on the opposite side of the Mediterranean most of whom were Muslims, although a few were Jews or Christians".

This also may explain as Homoud (1985:24) pointed out, the origin of the concept that the first bank worthy of this nomenclature was that which was established in Venice in the year $1157 \mathrm{AD}$, and what became common knowledge about dating the origin of banking operations back to the money changers in Lombardia who used to sit behind their wooden desks, known as banco. Thus, as Lopez (1952:291) remarked: "Italy was to the Medieval economic process what England was to the modern. Even as the industrial revolution first transformed economy and society in some English areas and spread later to the rest of the world, the commercial revolution (trade and banking)

first affected a few Italian cities and then made its way slowly through the rest of Europe".

\section{Banking in the Muslim World from the Fall of the Islamic Empire to the Emergence of What is Known as 'Islamic Banking'}

From the $11^{\text {th }}$ Century AD, time when the Islamic Empire started declining till about the mid- $20^{\text {th }}$ Century AD the Muslim World underwent long centuries of prolonged decay and deterioration, known as Usur-al-Inhitat or 'the Ages of Decline' just as Western Europe underwent the 'Dark Ages' from the fall of the Roman Empire till the end of the $12^{\text {th }}$ Century. A deterioration which affected all aspects of life: political, economic, social and cultural. The damaging consequences were disastrous:

- $\quad$ The once united caliphate became divided into tens of petty dynasties fighting each other. Despotism, tyranny and injustice became widespread. This made it easy for the Mongols, the Tartars, the Crusaders and others to invade, dominate and colonise the Muslim world.

- The once just and balanced Islamic society, based on the principles of the Shari'ah, was transformed into militaristic feudal societies that were much less conducive to economic and social development.

- Bayt al-mal (the treasury), which used to care about the poor, the destitute, the old and the young became the monopoly of the governors, ministers, military commanders and tax farmers. As a result, the general public lost confidence and withdrew from urban prosperous centres to hills in the countryside and to deserts to escape oppression, injustice, execution and confiscation. Ignorance, illiteracy, superstition, mysticism, idolatry, etc., all became widespread (see Issawi, 1966:4).

- $\quad$ Agriculture shrank to a minute fraction of what it had been in the $10^{\text {th }}$ Century and the population had correspondingly diminished. Land was granted or taken by officers. Farm techniques remained almost unchanged. Perhaps until the 1960s most farmers used only wooden ploughs instead of iron ones. As a 
result, yields were very low and both crops and livestock continued to be affected by droughts, pests and diseases (see Lewis, 1970:105, 113 and Issawi, 1966:3, 21, 65).

- The flood of European machine-made consumer goods brought by settlers dealt a severe blow to local handicrafts, many of which were wiped out in the following decades. One has only to compare the industrial products of the 18th Century with those made a few hundred years earlier to realise that the handicrafts had not only stagnated but had actually retrogressed (Issawi, 1966:4, 18 and 46).

- From the 11th Century, trade was transferred from the Muslims to the Europeans who soon became the main carriers and traders in the Mediterranean Sea. (Issawi,1966:7; and Lewis, 1970:114).

As reported by Vogel and Hayes (1998:19 and 4) from the middle of the nineteenth century, nearly every Muslim country, under direct or indirect pressure from the newly dominant West, adopted laws and legal systems based on Western models, particularly in the civil and commercial spheres. The centuries-old practice of finance in Islamic form was largely eclipsed. Under the European influence, most countries adopted Western inspired banking systems and business models and abandoned Islamic commercial practices. With the achievement of independence, the nationalisation of foreign banks and the development of national banking, the overseas colonisation of the banks disappeared, but it has been replaced by a very similar 'neo-colonial' banking system. It is true that by nationalising foreign banks and by establishing new indigenous banks, these banks became national banks, looking after the national interests, but their operating systems was the same as the foreign ones in that they continued to operate and deal in interest which is alien to the belief of the Muslim population. Thus, the idea of establishing 'Islamic banks' -which would not only offer all banking services, but which would not break or violate the religious beliefs of the people - arose. The idea of creating 'Islamic Banks' or 'Interest-Free Banks' as they are also called, came as a result of the Islamic revival which can be traced back to the 1930s, 1940s and 1950s, when some of the colonised Islamic countries became independent.

The first attempt to establish an Islamic Bank was made, as Traute (1983) and Wilson (1983) pointed out, in the late 1950s in a rural area in Pakistan, though this had no lasting impact. A small experimental Interest-Free Bank was founded by a small number of pious landowners who were prepared to deposit funds without interest rewards. The credit was advanced to other poorer landowners for agricultural improvements. No interest was charged for the credit, but a small fixed administrative fee was levied to cover the operating costs of the bank. However, as Wilson (1983:75) put it: "although there was no shortage of borrowers, the depositors tended to view their payments in the institution as a once and for all effort and the institution soon ran short of funds. In addition, the depositors took a considerable interest in how their deposits were loaned out and the bank officials enjoyed little autonomy with no new deposits forthcoming, and problems over recruitment of bank staff, who were unwilling to give up lucrative and secure careers in city commercial banking for an uncertain venture in the countryside, the institution soon foundered... But just as the Pakistan venture was being ended a new experiment was being tried in Egypt" 
On $25^{\text {th }}$ July 1963, a pioneering experiment, the Mit-Ghamr Islamic Savings Bank (MGISB), started in the county of Mit-Ghamr in Egypt by el-Naggar who later became Secretary General of the International Association of Islamic Banks. The model was the German savings banks adapted to the rural environment of an Islamic developing country. The purpose was to mobilise the idle savings of the majority of the Muslim Egyptian population without transgressing the laws of the Shari'ah and to provide them with halal returns on their savings as well. Although el-Naggar, was primarily an academic himself, he managed the bank and carefully selected the bank's staff from enthusiast Muslims, who had some banking experiences with commercial institutions. "The staff soon gained the confidence of the conservative county community who saw they were devout Muslims like themselves, as they worshipped locally with their potential customers. The region's peasants were suspicious of outsiders and few had ever used commercial banks, which were seen as alien institutions belonging to the cities, and mainly to serve westernised Egyptians. These new bankers were viewed as different, as they shared the same views and moral values as the peasants themselves, despite their education" (Wilson, 1983:76).

According to its founder and manager, el-Naggar (1974:246-247), the role of this bank was threefold: first, to act as an efficient intermediary between the supply and demand of capital; second, to act as an educational centre for economic efficiency, saving education and banking habit; and third, to set a dynamic factor in mobilising the idle capital for investment, thus, reducing hoarding and the problems of capital formation.

Wilson (1983:76) reported that: "The bank's loans were used for a variety of purposes including house building and repairs, the purchase of simple machinery for handicraft industries, such as hand-looms for weaving textiles or... sewing machines. Some loans helped finance the purchase of farm animals and basic improvement to the irrigation systems as efficient water provision was essential in a community based on agriculture". MGISB soon prospered, and within three and a half years, the first depositors were joined by more than 251,000 and the deposits grew at unprecedented higher rates than expected (see Table 1. which compares the growth of its total deposits to that of the Egyptian Banking System (EBS) as a whole in current and constant prices during the same period and tables 2., 3. and 4. which show the number of depositors, the size of the average deposit, the number of branches and the kinds of depositors who were banking with this Islamic bank). 
Table 1. Comparative Analysis of the Total Deposits in the EBS and in the Mit-Ghamr Islamic Savings Bank for the period 1964-1967

In Current Prices

\begin{tabular}{|c|c|c|c|c|c|c|}
\hline $\begin{array}{l}\text { Years } \\
\text { in EL }\end{array}$ & $\begin{array}{c}\text { EBS's TLD } \\
\text { in } \%\end{array}$ & $\begin{array}{r}\text { Index } \\
\text { in \% }\end{array}$ & $\begin{array}{l}\text { Growth } \\
\text { in EL }\end{array}$ & $\begin{array}{l}\text { MGISB's TLD } \\
\text { in } \%\end{array}$ & $\begin{array}{l}\text { Index } \\
\text { in } \%\end{array}$ & Growth \\
\hline 1964 & $378,000,000$ & 100 & - & 40,944 & 100 & - \\
\hline 1965 & $396,000,000$ & 105 & 5 & 191,235 & 467 & 367 \\
\hline 1966 & $415,000,000$ & 110 & 5 & 879,570 & 2148 & 360 \\
\hline 1967 & $445,000,000$ & 118 & 7 & $1,828,375$ & 4466 & 108 \\
\hline \multicolumn{2}{|c|}{ Averages } & \multicolumn{2}{|l|}{6} & \multicolumn{3}{|c|}{278} \\
\hline \multicolumn{7}{|c|}{ In Constant Prices } \\
\hline 1964 & $364,513,010$ & 100 & - & 39,483 & 100 & - \\
\hline 1965 & $332,214,760$ & 91 & -9 & 160,432 & 406 & 306 \\
\hline 1966 & $319,722,650$ & 88 & -4 & 677,635 & 1716 & 322 \\
\hline \multirow[t]{2}{*}{1967} & $340,474,360$ & 93 & 7 & $1,398,910$ & 3543 & 106 \\
\hline & rages & \multicolumn{2}{|c|}{-2} & \multicolumn{3}{|c|}{245} \\
\hline
\end{tabular}

Sources: IMF International Financial Statistics and El-Naggar (1974).

Abbreviations: EBS: Egyptian Banking System; MGISB Mit Ghamr Islamic Saving Bank.

Table 2. The Number of Depositors and their Average Deposits in Mit-Ghamr Islamic Savings Banks

\begin{tabular}{ccccc}
\hline Years & $\begin{array}{c}\text { No of } \\
\text { Depositors }\end{array}$ & $\begin{array}{c}\text { Growth } \\
\text { in \% }\end{array}$ & $\begin{array}{c}\text { Average Deposit } \\
\text { Per Saver }\end{array}$ & $\begin{array}{c}\text { Growth } \\
\text { in \% }\end{array}$ \\
\hline 1964 & 17,560 & - & 2.33 & - \\
1965 & 30,404 & 73 & 6.29 & 170 \\
1966 & 151,998 & 400 & 5.79 & -1 \\
1967 & 251,152 & 65 & 7.28 & 26 \\
\hline
\end{tabular}

Source: El-Naggar (1974:271)

Table 3. Mit-Ghamr Islamic Savings Bank’s branches Between 1963-1967

\begin{tabular}{llll}
\hline Branch Name & Opening Date & Branch Name & Opening Date \\
\hline 1 Mit Ghamr & $05-07-1963$ & 6 Zefti & $09-02-1966$ \\
2 Sharbine & $14-08-1965$ & 7 Al Mahallah & $24-07-1966$ \\
3 Al Mansoura & $11-09-1965$ & 8 Misr Al-Jadidah & $23-07-1966$ \\
4 Dakerous & $09-10-1965$ & 9 Belqaa & $01-10-1966$ \\
5 Kasr Al Ayni & $14-10-1965$ & & \\
\hline
\end{tabular}

Source: El-Naggar (ibid) 
Table 4. Percentage Share of Savings and Investment Deposits in Total Deposits of Different Groupings of Savers in MGISB

\begin{tabular}{ccl}
\hline Savings Deposits & Investment Deposits & Depositors \\
\hline 53.5 & 38.0 & Students \\
14.0 & 12.0 & Workers \\
2.3 & 12.8 & Pensioners \\
0.2 & 22.0 & Civil Servants \\
5.1 & 6.4 & Housewives \\
10.9 & 15.9 & Peasants \\
2.0 & 2.4 & Merchants \\
2.0 & 2.0 & Others \\
\end{tabular}

Source: el-Naggar (1974:272)

It is quite clear from the comparative tabular analysis of the little data available, that this experiment proved quite successful and the savings mobilisation impressive. Its success in winning the support of a large number of students, farmers and villagers who regarded the bank as their own, is discussed by Ready (1967); El-Naggar (1974), Harvey (1981); Traute (1983) and Wilson (1983). El-Naggar (1974:272) commented: "In spite of the short period during which the bank has been in operation, it has rendered vital services to the economic development of the local community, especially in the development and the establishment of small industries and in providing new opportunities of work for unemployed workers in Mit-Ghamr and its 53 affiliated villages".

It is said that this bank was so successful that it would have covered the whole of Egypt by now, if it has not been stopped for political reasons outside its control. It came to an end in February 1967 after only three and a half years during which problems of rural indebtedness were reduced in the areas where this bank and its branches were operating. Borrowers, no longer, had to depend neither on the few local moneylenders, many of whom charged high interest rates, nor on the non Islamic banks which consider them as a 'non-bankable class' and which, they themselves would not deal with, as these banks base their operations on Riba (interest) which is Haram according to their belief in Islam.

El-Naggar (1978:230-232) reported that: Paradoxically, yet not surprisingly, it has been its success, rather than the reverse, which has created problems for the bank. As soon as the social role of the bank began to make itself evident in the successful development of the local area, conflicts started with the local social authorities who saw it as interfering in their own area of authority and regarded it as simply reduplicating their own efforts unnecessarily. In the meantime, because the bank introduced a new concept of banking more expressive of Islamic belief and practice and firmly rooted in a popular Muslim base the size of savings and number of savers was increasing rapidly either by the addition of new savers, or by savers who transferred their money from the commercial banks to the Islamic one. Inevitably this aroused the traditional banks against their new popular based and progressive competitor... Thus, in furthering such changes, the functions and role of the bank could, from a narrow view-point, be regarded as conflicting with existing institutions such as the social authorities, the 
commercial banks and some of the central holding organisations: industrial or commercial which were mainly under government control, so it was stopped. Nevertheless, the venture laid the seeds of modern Islamic banking and pointed the way for subsequent undertakings. Soon afterwards many Islamic social, developmental and commercial banks started doing business following the example of Mit-Ghamr Islamic savings bank with some improvements. The first of such banks is the Nasser Social Bank established in 1971 in Egypt, not as profit oriented institution but as a social bank to serve the previously 'unbankable' low income group; followed by the Islamic Development Bank (IDB), an Inter-governmental institution established in 1975 in Jeddah (Saudi Arabia), with the purpose to foster the economic and social development of its member countries, and by the Dubai Islamic Bank (DIB) in Dubai (UAE) in 1975, the first major Islamic commercial bank, the success of which led to the establishment of a series of such banks elsewhere.

Another successful experiment in this regard, that happened approximately at the same time as Mit-Ghamr savings bank, is the birth of the Pilgrims Fund Corporation or Tabung Haji, which started operation in Malaysia in 1963 with the following objectives:

- To enable Malay Muslims to save gradually, in order to support their expenditure during Hajj (pilgrimage) and for other beneficial purposes.

- To enable Malay Muslims to have active and effective participations in investment activities that are permissible in Islam through their savings.

- To protect, safeguard the interests and ensure the welfare of pilgrims during pilgrimage by providing various facilities and services.

With such objectives in mind, Tabung Haji has been running successfully since then. It has provided excellent and comprehensive services with premium quality to satisfy the pilgrims need prior, during and after their pilgrimage. Its existence was attributed to a working paper presented by the Royal Professor Ungku Aziz titled, "Plan to Improve the Economy of Prospective Pilgrims” in 1959 (Tabung Haji website).

Started its business in 1963 with only 1281 members and a total deposits of MR46,600, the quasi-government body now has a membership (account holders) of around 4 million and deposits of more than US\$2 billion. The number of account holders when seen in proportion to the total Malaysian Muslim population, i.e. 12 million, is an indicator of how popular and successful this experiment is in Malaysia (Rahman, 2004).

Tabung Haji operates as an alternative financial institution to interest based banks, providing halal investment opportunities to Malaysian Muslim savers. Any Malaysian Muslim can open his or her account with Tabung Haji with a minimum monthly instalment of RM10 for adults and RM2 for children. It has a network of 111 branches that serve its members, in addition to the use of the services of the post offices, and deductions from salaries. As regards to withdrawal, it is as simple as in any financing institution. An additional facility for Tabung Haji account holders is that a special withdrawal network is also available to them during Hajj in Saudi Arabia. The amounts collected are invested in selected investment projects spread across a diverse range of investment portfolios in conformity with Shari'ah guidelines and strong growth 
potentials. At present, the total value of its investment is around US\$4billion. This includes short and long-term investments, equity investments, unit trust investments, schemes offered by government, real estate investments as well as investments in its 12 subsidiary companies, which are engaged from the traditional sectors of agricultural, plantation or real estate business to the most modern Information Technology. Since 1995, Tabung Haji has been allowed to expand its operating framework, and now it is able to extend its business activities even outside Malaysia (ibid.).

At present, in addition to the Islamization of the Iranian, Pakistani and Sudanese banking systems, there are, according to the General Council of Islamic Banks and Financial Institutions (GCIBFI, 2001), more than 270 Islamic financial institutions worldwide, having assets over US $\$ 300$ billion, deposits over US\$200 billion and investments over US\$160 billion. Most of these institutions were established in the late 1970s and early 1980s in such countries as Egypt, Kuwait, Jordan, Bahrain, Qatar, Malaysia, Bangladesh, Senegal, Tunis, Turkey, Algeria, Senegal, Indonesia, etc., and most of them have been able to mobilise substantial amounts of deposits, acquire a notable share in the national market and generate sizable profits from their first year of operation, in spite of the shortness of the period, the competition from the interest-based banks and the problems related to the non-Islamic environments in which they operate. In fact, there are Islamic Banks and Islamic Investment Companies in the West as well, as in Switzerland, Denmark, Luxembourg, England, etc.. Not only that, but large and famous non-Islamic banks such as Citibank, HSBC, and others have opened 'Islamic banking windows' to put their hands on this fast growing sector.

Many other Islamic non-bank financial institutions were also established in many parts of the world, such as, insurance companies under the name of Takaful companies and some other investment companies. The primary objectives of these Islamic Financial Institutions is to provide an alternative to exploitative capitalist system and a riba-free mode of banking that mobilises dormant resources of devout Muslims who are reluctant to deal with interest-based banks because of riba. And as pointed out by Tarbush (1981:6): "they apparently have no problem in achieving this goal. It is claimed that on its first day of opening to the public the Kuwait Finance House (the Islamic Kuwaiti bank) received KD50m (US\$140m) transferred from deposits of the commercial banks". The available data, on some of the existing Islamic Banks, reveal that many of them have even been able to acquire considerable amounts of assets that they qualify for ranking among the top 100 Arab largest banks and that they are improving (See table 5. showing the position of some Islamic Banks, in some Arab countries, among the top 100 Arab Banks). 
Table 5. Position of some Islamic Banks among the top 100 Arab Banks

\begin{tabular}{|c|c|c|c|c|c|c|c|}
\hline Year & $\mathrm{KFH}$ & FIBE & QIB & DIB & JIB & SBB & RBIC \\
\hline 1980 & 94 & - & - & - & - & - & - \\
\hline 1981 & 68 & - & - & - & - & - & - \\
\hline 1982 & 51 & 77 & - & - & - & - & - \\
\hline 1983 & 42 & 66 & - & - & - & - & - \\
\hline 1984 & 34 & 47 & - & - & - & - & - \\
\hline 1985 & 39 & 45 & - & 97 & - & - & - \\
\hline 1986 & 36 & 43 & - & 87 & 87 & - & - \\
\hline 1987 & 28 & 48 & - & 93 & 85 & - & - \\
\hline \\
\hline 2000 & 24 & 90 & 91 & 48 & 96 & 58 & - \\
\hline 2001 & 21 & 95 & 86 & 48 & 97 & 54 & - \\
\hline 2004 & 21 & - & 90 & 38 & - & 58 & 6 \\
\hline
\end{tabular}

Source: The Banker, various issues.

Abbreviations: KFH: Kuwait Finance House; FIBE: Faisal Islamic Bank of Egypt; QIB: Qatar Islamic Bank; DIB: Dubai Islamic Bank; JIB: Jordan Islamic Bank; SBB Shamil Bank of Bahrain; RBIC Rajhi Banking and Investment Corporation.

This shows, as Nienhaus (1988:90) remarked that: "these Islamic Banks have grown to financial institutions of a respectable size within a relatively short period of time". Some of them like KFH, FIBE, JIB and SSB have become among the seven largest banks in their respective countries and despite a slow down in their rates of growth their market shares in the mobilisation of deposits and the allocation of funds have grown considerably.

\section{Conclusion}

Historical evidence on the origin and development of banking and finance, shows that banking operations have been known to many civilizations, long before the $12^{\text {th }}$ Century Italy which is considered by most economists as the 'birth place of banking'. Banking operations have been practiced in earlier civilisations, such as the Islamic, the Roman, the Greek, the Egyptian and even the Babylonian and the Sumerian. In fact, there is available historical evidence which dates as early as 34 centuries BC (i.e. 5,400 years ago) and which shows that a very advanced banking system was carried out by the religious temples which used to take care of the savings of their depositors and give loans to those who need finance, thus acting as banks. In other words banking, as Homoud (1985:16-17) pointed out: "was known in various forms and guises in a number of cultures which flourished in various parts of the world before they lapsed into oblivion".

We also saw how modern banking was developed in Europe and later transferred to the Muslim World, and how Islamic banking came about to fill the gap that modern interest-based banks could not fill in the Muslim World, because of the reluctance of the Muslims to deposit their savings with interest-based banks, due to their Islamic belief that interest is $\underline{\text { riba }}$ and $\underline{\text { riba }}$ is the most strictly prohibited thing in Islam. 


\section{References}

Al-Ali, Saleh, (1953) al-Tanzimat al-Ijtimaiyyah wa al-Iqtisadiyyah fi al-Basrah (The Social and Economic Organisations in al-Basrah), Dar al-Kutub, Baghdad.

Al-Ali, Saleh, (1953a) Muhadarat fi Tareekh al-Arab Qabl al-Islam (Lectures on the History of the Arabs before Islam), Dar Al-Kutub, Baghdad.

Bamboo (website): "History of Paper Money ", in http://www.bambooweb.com/articles/b/a/ Banknote.html

The Banker, Various Issues between 1980 and 2002.

Bantier, R. H. (1971) The Economic Development of Medieval Europe, Thames and Huddson, London.

Bergier, J. (1979) "From the Fifteenth Century in Italy to the Sixteenth Century in Germany: A new Banking Concept" in The Centre for Medieval and Renaissance Studies, (eds.) The Dawn of Modern Banking, University of California, Los Angeles.

Birnie, A. (1933) An Economic History of Europe 1760-1930, Mathuen, London.

Blomquist, T. (1979) "The Dawn of Banking in an Italian Commune: Thirteenth Century Lucca" in The Dawn of Medieval Banking, (ed.) By The Centre For Medieval and Renaissance Studies, California University Press, Los Angeles.

Chapra, M. U. (2000) The Future of Economics: An Islamic Perspective, The Islamic Foundation, Leicester

Chapra, M. U. and H. Ahmed (2002) Corporate Governance in Islamic Financial Institutions, Occasional Paper No.6, Jeddah, IRTI/IDB.

Chapra, M. U. and T. Khan (2000) Regulation and Supervision of Islamic Banks, Occasional Paper No.3, Jeddah, IRTI/IDB.

Davies, G. (2002) A History of Money from Ancient Times to the Present Day, university of Wales Press, Cardiff.

De Roover, R. (1954) "New Interpretation of the History of Banking", Journal of World History, Vol. 2.

Delaporte, L. (1925) Mesopotamia, A.K. Alfred, New York.

Al-Djahshiyari, A. (1938) Kitab al-Wuzara'wa al-Kuttab (The book of Ministers and Writers), Cairo.

Doi, A.H. (1984) Shariah, The Islamic Law, Taha Publishers, London.

Al-Duri, Abdul Aziz (1986) "Baghdad" in the Encyclopaedia of Islam, Brill, Leiden, Vol.1, pp. 894-909

Al-Duri, Abdul Aziz (1986a) Tarikh al-Iqtisadi lil-Iraq (The Economic History of Iraq), Matbaat Al-Maarif, al-Baghdad.

Einzig, P. (1949) Primitive Money, Eyre and Spottiswood, London

Encyclopedia Iranica, Center For Iranian Studies, Columbia University, 1989.

Findling, J. and F. Thackeray, (2001), The History of China, Greenwood Press, Westport.

Fischel, W. J. (1992) "Djahbadh" in the Encyclopedia of Islam, vol. 2, Prill, Leiden.

Frank, T. (1933) An Economic Survey of Ancient Rome, Hopkins, Baltimore.

GCIBFI, (2001) The website of the General Council of Islamic Banks and Financial Institutions: http://www.islamicfi.com/arabic/research/Research Archivefull.asp?id=62855

Gerschenkron, A. (1962) Economic Backwardness in Historical Perspective: A Book of Essays, Harvard University Press, Cambridge Mass.

Ghirshman R., V. Minorsky and R. Sanghir (1971) Persia the Immortal Kingdom, Orient Commerce Establishment, N. York.

Goitein, S.D. (1967) A Mediterranean Society: The Jewish Community of the arab World as portrayed in the Documents of the Cairo Geniza, University of California Press, California

Goitein, S.D. (1973) Letters of Medieval Jewish Traders, Princeton University Press, Princeton, N. Jersey.

Al-Hamdani, Khaled (2000) "al-Nizam al-Masrafi fi al-Dawlah al-Islamiyah" (The Banking System in the Islamic State), Islamiyat al-Maarifa, Winter, pp.15-41

Harvey, N. (1981) "World Islamic Finance Based On Community Banks", Saudi Business, 20/3/1981. 
Heichelhein, F.M. (1958) An Ancient Economic History, A.W. Sijthoffs Uitgeveraat-Schapping, N.V, Leiden.

Herart, C. (1972) Ancient Persia and Iranian Civilization, Routledge \& Kegan Paul, London

Hitti, P. K. (1970) History of the Arabs, Macmillan, London.

Homer, S. (1963) A History of Interest Rates, Reutgers University Press New Brunswick, New Jersey.

Homoud, S. H. (1985) Islamic Banking, Arabian Information, London.

Issawi, C. (1966) The Economic History of The Middle East 1800-1914, University of Chicago Press, Chicago.

Al-Kubaisi, Hamdan (1979) Aswaq Baghdad Hatta Nihayat al-Asr al-Buwaihi, (Baghdad's Markets until the end of the Buwaihi era), Dar al-Hurriyah, Baghdad.

Labib, S. (1969), “Capitalism in Medieval Islam”, Journal of Economic History, Vol.29, No.1, March 1969, pp. 79-140.

Lewis, A. (1954) Economic Development with Unlimited Supplies of Labour, Manchester School of Economics, Manchester.

Lewis, B. (1970), Cambridge History of Islam, Cambridge University Press, Cambridge

Lieber, A.E. (1968) "Eastern Business Practices and Medieval European Commerce", Economic History Review, Vol. 21, 1968, pp. 230-243.

Lopez, R. (1952) "The Trade of Medieval Europe: the South", Cambridge Economic History of Europe, Vol. 2, Cambridge University Press.

Lopez, R. (1979) The Dawn of Medieval Banking, (ed.) by The Centre For Medieval and Renaissance Studies, University of California, Los Angeles.

Metwally, A. and S. Shahata (1983) Iqtisadiat-al-Uqud fi Itar al-Fikr al-Islami (The Economics of Money in the Islamic thinking), Dar Al-Tawfiq al-Namudhajiyah Littiba'a wal-Jam'e Al-Ali, Cairo.

Mez, Adam (1937) The Renaissance of Islam, Luzac and Co., London, 1937.

Miskimin, H.A. (1969) The Economy of Early Renaissance Europe 1300-1460 Prentice Hall, Englewoods Cliffs, New Jersey.

El-Naggar, A. (1974) Al-Madkhal li al-Nadhariah al-Iqtisadia fil-Manhaj al-Islami, (Introduction to the Economic Theory within the Islamic Methodology", Dar al-Fikr, Cairo.

El-Naggar, A. (1978) "Islamic Banks: A Model and a Challenge" in Gauhar (ed.) The Challenge of Islam, Economic Council of Europe, London.

Nationmater (website), www.nationmaster.com/encyclopedia/Indus-Valley-Civilization

Netfundu (Website), www.netfundu.com/junior/historyofbanking.htm

Netfundu (Website), www.netfundu.com/junior/bankingindia.htm

Nienhaus, V. (1983) Directions of Trade among Islamic Countries: Levels, Growth Rates, Rank Orders, Concentration and Polarisation, University of Bochum, Bochum.

Nienhaus, V. (1985a) "Islamic Economics, Finance and Banking: Theory and Practice", Paper Presented at the London Conference on Islamic Banking and Finance, 31/1/1985 $1 / 11 / 1985$.

Nienhaus, V. (1988) "The Performance of Islamic Banks: Trends and Cases" in C. Mellat (ed.) Islamic Law and Finance, SOAS, London.

Nienhaus,V. (1985b) "Principles, Problems and Perspectives of Islamic Banking", Intereconomics, Vol.20, No.5, Sep/Oct. 1985.

Nigam, S. (1975) Economic Organisations in Ancient India (200 BC-200AD), Munshiram Manoharlal Publishers, New Delhi

Orsingher, R. (1967) Banks of the World, Macmillan, London.

Pellat, C. and J. Schacht (1965) Encyclopedia of Islam, L. Luzac, London.

Pirenne, H. (1937) Economic and Social History of Medieval Europe, Harcourt Brace \& Co. New York.

Al-Qalqashandi, A. (1913) Subh al-A 'Asha fi-Sinaat al-Insha, Cairo.

Rahman, K. (2004) "Towards Islamic Banking: A Case Study of Pilgrims Management \& Fund Board, Malaysia" in Eldis website: http://www.eldis.org/fulltext/rahman.pdf 
Ready, R. (1967) “The Egyptian Municipal Saving Banks Projects”, International Development Review, Vol.9, June 1967, pp.2-5.

Rhodes, S. (2003) "The History of Credit and Debt", Steve Rhodes' website Myvesta.org Inc. http://myvesta.org/history/

Al-Sa'di Amal (1985) al-Sayrafah wal-jahbadhah fi al-Iraq (Money Changing and Banking in Iraq), PhD Thesis, Univerity of Baghdad

Saletore, R.N. (1975), Early Indian Economic History, Curzon Press, London.

Al-Sayid, A. (1984) 'Al-Muslimuna yunshiuna Awwal Masraffil-Alam' (The Muslims Establish the First Bank in The World) Al-Madinah newspaper No. 6214, page 17.

Scott C. L. (2003) "India V. Indo-Persian Commercial Relations" in Iranica website: http://www.iranica.com/articlenavigation/index.html

Steigher, A. (1963) Origin and Spread of Oriental Words in European Languages, N.York

Tarbush, M. (1981), "The Tide of Islamic Banking” in Financial Times, 28/9/1987.

Tejarat (1998) The Internal Publication of Bank Tejarat, Winter 1998, No. 8

Torrey, C. (1892) The Commercial Technical Terms in the Koran, Leyden.

Traute, W. and V. Nienhaus (1982) "Arab and Islamic Banks, Petrocapital and Development", Orient-German Journal of Politics and Economics of the Middle-East, Vol.23, June 1982, pp.243-259.

Traute, W.S. (1983), Arab and Islamic Banks, OECD, Paris.

Udovitch, A. (1970) Partnership and Profit in Medieval Islam, Princeton University Press, New Jersey.

Udovitch, A. (1979) "Bankers Without Banks: Commerce, Banking and Society in the Islamic World of the Middle-Ages" in The Dawn of Modern Banking, (ed.) by the Centre for Medieval and Renaissance Studies, University of California, Los Angeles.

Usher, A. (1943) The Early History of Deposit Banking in Mediterranean Europe, Cambridge Mass.

Vives, J.V. (1969) Economic History of Spain, Princeton University Press, New Jersey.

Vogel, F. and S. Hayes (1998) Islamic Law and Finance, Kluwer Law International, The Hague.

Weit, G. (1955) "Les Marchands d'Epices sous les Sultans Mamlouks", Cahiers d'Histoire d'Egypt, Paris.

Wikipedia (website), http://en.wikipedia.org/wiki/Indus Valley Civilization\#Economy

Wilson, P. R. (1950) "The Empire of the Prophet: Islam and the Tide of Arab Conquest" in D. Talbot (ed.) The Dark Ages, Thomas and Hudson, London.

Wilson, R. (1983) Banking and Finance in the Arab Middle East, Macmillan, Surrey. 


\section{أصل وتطور العمليات المصرفية التجارية والإسلامية}

$$
\begin{aligned}
& \text { عبد القادر شاشي } \\
& \text { باحث } \\
& \text { مركز أبجاث الاقتصاد الإمسلامي باحي } \\
& \text { جامعة الملك عبد العزيز- جلدة - المملكة العربية السعودية الإسلادية } \\
& \text { المستخلص: معظم الاقتصاديين يعتبرون أن الصسيرفة أداة عصسرية حديثـة المنشـأ (إيطاليـا في }
\end{aligned}
$$

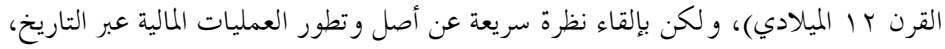

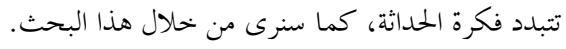

$$
\begin{aligned}
& \text { الهدف من هذا البحث هو: } \\
& \text { أو لا: تبيين أن العمليات المصرفية كانت مطبقة في كل الحضارات القديمة المعروفة، قبل } \\
& \text { إيطاليا القرن الثاني عشر الميلادي. تيدن أن العمات المصرف } \\
& \text { ثانيا: إثبات أن الإسلام لم يسمح بهذه العمليات فقط، وإنما شجعها إلى حد فاق كل }
\end{aligned}
$$

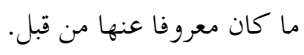

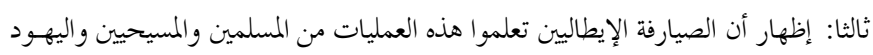

$$
\begin{aligned}
& \text { الذين كانت تربطهم بهم علاقات بتحارية قوية بين القرن العاشر والقرن الثاني عشر المبلين الميلاديين. } \\
& \text { وأخيرا، تتبع أصل وتطور ما يسمى بالبنوك الإسلامية. }
\end{aligned}
$$

